\title{
Article
}

Arq Neuropsiquiatr 2011;69(5):766-769

\section{Mortality in children with severe epilepsy \\ 10 years of follow-up}

\author{
Vera C. Terra ${ }^{1}$, Fulvio A. Scorza², Ricardo M. Arida ${ }^{3}$, \\ Regina M.F. Fernandes', Lauro Wichert-Ana4, \\ Helio R. Machado', Américo C. Sakamoto'
}

\begin{abstract}
Epilepsy is the main neurological condition in children and adolescents. Unfortunately patients with medical refractory epilepsy are more susceptible for clinical complications and death. We report a prospectively evaluated cohort of children followed for approximately 10 years. Fifty-three of 1012 patients died. Forty-two patients died due to epilepsy or its clinical complications and the main causes of death were pneumonia (in 16 cases), sepses (in 9 patients), status epilepticus (in 8 patients). In 11 patients cause of death was sudden unexpected death in epilepsy (SUDEP). Mental retardation was significantly more frequent in patients who did not die from SUDEP. SUDEP may be a significant condition associated with mortality in children and adolescents with epilepsy. Key words: epilepsy, mortality, sudden death, children.
\end{abstract}

\section{Mortalidade em crianças com epilepsia severa: 10 anos de seguimento}

\section{RESUMO}

Epilepsia é uma das condições neurológicas mais comuns em crianças e adolescentes. Infelizmente, pacientes com epilepsias refratárias ao tratamento medicamentoso estão mais susceptíveis a complicações clínicas e óbito. Neste trabalho reportamos, em uma análise prospectiva, um cohort de crianças acompanhadas por aproximadamente dez anos. Cinquenta e três de 1012 pacientes foram a óbito. Quarenta e dois pacientes morreram em decorrência da epilepsia ou de suas complicações clínicas; as principais causas foram pneumonia (16 casos), sepse ( 9 casos) e estado de mal epiléptico ( 8 casos). Em 11 pacientes a causa da morte foi SUDEP. A presença de retardo mental foi significantemente associada a mortalidade em crianças e adolescentes com epilepsia.

Palavras-Chave: epilepsia, mortalidade, morte súbita, crianças.

\section{Correspondence \\ Vera Cristina Terra \\ Depto. de Neurologia - CIREP \\ Campus Universitário \\ 14048-900 Ribeirão Preto SP - Brasil \\ E mail: v.c.terra@rnp.fmrp.usp.br}

\section{Support}

The authors thank to FAPESP, CInAPCe-FAPESP, CNPq and FAEPA

for supporting this study

\section{Conflict of interest}

The authors report no conflict of interest

Received 20 February 2011

Received in final form 10 May 2011

Accepted 25 May 2011
Epilepsy in children is a major health problem with an incidence ranging from 20 to 190 cases/100,000 inhabitants ${ }^{1}$. Epilepsy is associated with a high probability of injury and with clinical comorbidities, and the reported mortality incidence in epileptic individuals is two to three times higher than that in the general population $^{1,2}$. The mortality incidence is not clearly determined in the development countries, but it appears to be more frequent in patients with mental retardation or with symptomatic epilepsy ${ }^{3}$. The lack of studies with a large number of pediatric patients, during a long-term period and involving standardized case selection, makes the comparison between the studies difficult ${ }^{4}$.

Sudden unexpected death in epilepsy (SUDEP) is probably the commonest di-

'Departamento de Neurociências e Ciências do Comportamento. Faculdade de Medicina de Ribeirão Preto, Universidade de São Paulo (FMRP/USP), Ribeirão Preto SP, Brazil; ²Disciplina de Neurologia Experimental, Universidade Federal de São Paulo/ Escola Paulista de Medicina (UNIFESP/EPM), São Paulo SP, Brazil; ${ }^{3}$ Departamento de Fisiologia, UNIFESP/EPM; ${ }^{4}$ Divisão de Medicina Nuclear, Centro de Ciências da Imagem e Física Médica, Departamento de Clínica Médica, FMRP/USP. 
rect epilepsy-related cause of death. Its incidence has been reported to be 1 per 100 person-years in patients with intractable epilepsy and 0.35 per 1,000 personyears in the general population ${ }^{5}$. There are few reports on death risks in the pediatric population solely, and only a small number of patients are usually analyzed ${ }^{6,7}$. We report here the mortality incidence in a cohort of children and adolescents with epilepsy, in a Brazilian hospital.

\section{METHOD}

This refers to a prospective study that evaluated the incidence of epilepsy-related death in a cohort of children aged from zero to 18 years, from January 2000 to November 2010, in the Clinical Hospital of Ribeirão Preto. During the follow-up, patients were evaluated regarding the demographic and clinical data - age at epilepsy onset, epilepsy syndrome, seizure frequency, antiepileptic drug therapy (AED) and neurological development. All cases with dubious diagnosis of epilepsy were excluded from the study. Families were contacted in order to elucidate the death causes. Epilepsy etiology was classified as symptomatic (with known cause), probably symptomatic (with unknown etiology) and idiopathic (when clinical and electrographic findings were clearly related to an idiopathic syndrome ${ }^{8}$ ). Patients with exclusive febrile seizures or with a single seizure were not considered in this study. All families that were contacted were asked to sign informed consent according to ethical guidelines.

The SUDEP criteria were: [1] Child with epilepsy and with recurrent unprovoked seizures; [2] Child who died unexpectedly while in a reasonable state of health; [3] Death that occurred suddenly; [4] Death that occurred during normal activities, under benign circumstances; [5] Unknown obvious medical cause of death; [6] Death that was not directly caused by status epilepticus. We considered probable SUDEP when all the above-mentioned criteria were present, but post-mortem data were not available. Possible SUDEP was considered when conclusive and post-mortem data were lacking ${ }^{8,9}$.

The data were evaluated by the SPSS statistical program and both descriptive and categorical variables (Chisquare and Student $t$ test) were considered. A p value $<.05$ was considered statistically significant.

\section{RESULTS}

A group of 1012 patients aged from zero to 18 years were monitored from January 2000 to November 2010. Epilepsy in that group was classified as: focal symptomatic (63.7\%), probably symptomatic $(20.8 \%)$ and idiopathic (15.5\%). Twenty-five patients (3\%) were lost during the follow-up. Fifty-three patients or 5.6 personsyear died during the study period; 31 of which were boys.
The epilepsy onset occurred between birth and 11 years of age (mean 1.5 years \pm 2.2 ). The mean age of death was 9.2 years \pm 5.7 (range: 2 to 23 years). All patients showed symptomatic epilepsy. Almost all patients presented daily seizures (71.7\%). Weekly seizures occurred in 17\% of the cases and rare seizures (one to two seizures/year) in $11.3 \%$ of the patients. Mental retardation was present in $92.5 \%$ of the patients (being mild in $17 \%$, moderate in $20.8 \%$, and severe in $54.7 \%$ ). All patients were under AED treatment: $9.4 \%$ of the subjects were being given one drug, $28.3 \%$ two drugs, $54.7 \%$ three drugs, and $7.5 \%$ four drugs. Serum AED concentrations at the time of death were not available.

Image findings revealed diffuse atrophy (32.1\%), destructive lesions (15.1\%), cortical developmental malformations (9.4\%) and gliosis (7.5\%). Other lesions included mesial temporal sclerosis (in three patients), leucodistrophy (in one patient), tuberous sclerosis (in one patient), hydrocephaly (in one patient), and Dandy-Walker Syndrome (in one patient). Normal brain image was observed in $15.1 \%$ of the cases.

The main causes of death were pneumonia (in 16 cases), sepses (in nine patients) and status epilepticus (in eight patients). In each case there was one patient who died from head injury, one from cardiac failure, one from acute complications due to epilepsy surgery, one from drowning, one from pulmonary embolism, one from metabolic acidosis, one from falciform anemia, one from chemotherapy (a patient with leukemia) and one from hemorrhagic cerebrovascular accident (a patient with mitochondrial epilepsy).

Neither a clinical nor a neurological cause of death could be identified in 11 patients and dying of SUDEP was considered. Seven patients were found dead in bed in the morning or after a daytime sleep and four patients died of subtle cardiorespiratory arrest, directly related to a seizure.

Comparison between patients with and without SUDEP did not show any significant statistical differences related to gender, to epilepsy syndrome, to MRI findings, to number of AED, to seizure frequency and to seizure type (Table). Patients with moderate or severe mental development retardation were at a significant greater risk of dying from causes other than SUDEP $(p=0.02)$.

\section{DISCUSSION}

The mortality rate in patients with epilepsy is $2-5$ times higher than that found in the general population ${ }^{10}$. Our series consist of a group of children and adolescents with epilepsy that had been prospectively evaluated over ten years. There were 53 death cases - 11 of SUDEP - in the group of 1012 patients. Some authors have reported an increase in both children and elderly adults' mortality, 
which is usually associated with neurological deficit and clinically associated diseases ${ }^{4}$. Mortality is rare in patients with idiopathic epilepsies, and that was not observed in our group, although idiopathic epilepsies had been observed in $15.5 \%$ of our patients. Those observations suggested that patients with symptomatic epilepsies were at greater risk of dying ${ }^{11}$.

Systemic infections were the main cause of death in our group, followed by SUDEP and status epilepticus. In the general population, SUDEP incidence is between 1:500 and 1:1,000 person-years, whereas it is close to 1:200 for patients with severe forms of epilep$\operatorname{sies}^{12}$. SUDEP mechanisms are not well understood and the possible factors that involve them may be cardiovascular system abnormalities, central apnea or primary brain failure, during or just after a seizure ${ }^{13,14}$. Genetic factors related to channel genes in the cardiac musculature may interfere in its normal depolarization/repolarization process, predisposing the subjects to cardiac failure, prolonged QT interval, and increased susceptibility to cardiac arrhythmias ${ }^{12}$.

The incidence of SUDEP in children and adolescents is highly variable, but it is thought to be extremely rare ${ }^{15-17}$. Nevertheless, SUDEP had been identified as being the cause of mortality in $12 \%$ of the children followed over a five-year period, suggesting that that incidence may not be so rare ${ }^{18}$.

Factors related to SUDEP in children may be different from those observed in adults. The role of mental retardation, of medically refractory epilepsy, of AED polytherapy, of subtherapeutic AED levels, of young age and of high seizure frequency, and the description of a seizure just before SUDEP still need to be clarified ${ }^{16}$.

In this study, almost all patients died at home (63\% died during their sleep) and post-mortem examinations were not performed. Therefore, definitive SUDEP could not be established. SUDEP is found to be more prevalent worldwide than assumed and some authors suggested that verbal autopsy may be the only means of establishing a possible or probable cause of death ${ }^{19}$. No correlation between the demographic data and the death risk was observed, except when developmental delay was considered. Patients that died from SUDEP and were not sleeping died during a seizure witnessed by parents or caregiver. Deaths that were not associated with SUDEP were more frequent in patients with moderate or severe cognitive and neurological impairment. Camfield and Camfield ${ }^{20}$ realized a long term follow up in a cohort of children with symptomatic generalized epilepsy and found that outcome was nearly always death or a life of dependency, although approximately $30 \%$ of the cases had seizure remission. Others authors also found an increased risk of unexpected death in patients with ep-
Table. Demographic data comparing patients with SUDEP and other death causes. Statistical analysis: Studant t test (numerical data) and $x^{2}$ (categorical data).

\begin{tabular}{|c|c|c|c|}
\hline & $\begin{array}{l}\text { SUDEP } \\
(n=11)\end{array}$ & $\begin{array}{l}\text { Not SUDEP } \\
\quad(n=42)\end{array}$ & $\begin{array}{c}p \\
\text { value }\end{array}$ \\
\hline \multicolumn{4}{|l|}{ Epilepsy onset (years) } \\
\hline Mean (SD) & $1.75(2.2)$ & $1.5(2.2)$ & 0.81 \\
\hline \multicolumn{4}{|l|}{ Age at death (years) } \\
\hline Mean (SD) & $7.3(4.1)$ & $9.7(5.9)$ & 0.23 \\
\hline \multicolumn{4}{|l|}{ Number of AED } \\
\hline One or two (\%) & $5(45.5)$ & $15(35.7)$ & 0.73 \\
\hline Three or four (\%) & $6(55.5)$ & $27(64.3)$ & \\
\hline \multicolumn{4}{|l|}{ Gender } \\
\hline Male (\%) & $5(45.5)$ & $26(61.9)$ & 0.49 \\
\hline Female (\%) & $6(55.5)$ & $16(38.1)$ & \\
\hline \multicolumn{4}{|l|}{ EEG } \\
\hline Focal (\%) & $6(55.5)$ & $29(69.0)$ & 1.0 \\
\hline Generalized (\%) & $2(18.2)$ & $10(23.8)$ & \\
\hline \multicolumn{4}{|l|}{ Seizure I } \\
\hline Focal (\%) & $4(36.4)$ & $13(30.9)$ & 0.73 \\
\hline Generalized (\%) & $7(63.6)$ & $29(69.1)$ & \\
\hline \multicolumn{4}{|l|}{ Seizure frequency } \\
\hline Rare (\%) & $2(18.2)$ & $4(9.5)$ & 0.59 \\
\hline More than once/month (\%) & $9(81.8)$ & $38(90.5)$ & \\
\hline \multicolumn{4}{|l|}{ Mental retardation } \\
\hline Normal + mild (\%) & $6(55.5)$ & $7(16.7)$ & 0.02 \\
\hline Moderate + severe (\%) & $5(45.5)$ & $35(83.3)$ & \\
\hline
\end{tabular}

ilepsy, most of the patients with intractable epilepsy ${ }^{21}$. This seems to contribute to our findings that patients with symptomatic epilepsy are more susceptible for clinical comorbidities, and hence death. Confirming this finding our group demonstrated that patients with refractory epilepsy that became seizure free after epilepsy surgery had a lower SUDEP rate ${ }^{22}$. Other authors demonstrated a higher risk of SUDEP in patients with extratemporal epilepsy ${ }^{23}$.

Although a higher mortality in boys had been reported ${ }^{4,6}$, we could not confirm that finding. We also did not find a relation between the number of AED and the risk of SUDEP. Some authors have suggested that polytherapy may have been associated with a more severe form of epilepsy, not representing a potential risk alone ${ }^{24}$.

In conclusion, our study has demonstrated that SUDEP may be a significant condition associated with mortality in children and adolescents with epilepsy and, therefore, this risk should be informed to parents. Measures to minimize SUDEP risks should include seizure control, reduction of stress, participation on physical ex- 
ercises and night supervision ${ }^{25}$. In this way, correct medication intake to the achievement of an optimal seizure control should be encouraged, and other causes of mortality should be prevented, especially in severely mentally retarded patients. A long-term follow-up of patients with chronic epilepsy and prospective studies in large populations should be the best way to finally identify the major risk factors involved in children and adolescents' SUDEP.

\section{REFERENCES}

1. Hauser WA. The prevalence and incidence of convulsive disorders in children. Epilepsia 1994;35(Suppl 2):S1-S6.

2. O'Donoghue MF, Sander JW. A historical perspective on the mortality associated with chronic epilepsy. Acta Neurol Scand 1997;96:138-141.

3. Carpio A, Bharucha NE, Jallon P, et al. Mortality of epilepsy in developing countries. Epilepsia 2005;46(Suppl 11):S28-S32.

4. Forsgren L, Hauser WA, Olafsson E, Sander JW, Sillanpää M, Tomson T. Mortality of epilepsy in developed countries: a review. Epilepsia 2005; 46(Suppl 11):S18-S27.

5. Nashef L. Sudden unexpected death in epilepsy: terminology and definitions. Epilepsia 1997;38(Suppl):S6-S8.

6. Donner EJ, Smith CR, Snead OC 3rd. Sudden unexplained death in children with epilepsy. Neurology 2001,57:430-434.

7. Morentin B, Alcaraz R. Sudden unexpected death in epilepsy in children and adolescents. Rev Neurol 2002;34:462-465.

8. Commission On Classification And Terminology Of The International League Against Epilepsy. Proposal for revised classification of epilepsies and epileptic syndromes. Epilepsia 1989;30:389-399.

9. Annegers JF, Coan SP. SUDEP: overview of definitions and review of incidence data. Seizure 1999;8:347-352

10. Lhatoo SD, Johnson AL, Goodridge DM, MacDonald BK, Sander JW, Shorvon SD. Mortality in epilepsy in the first 11 to 14 years after diagnosis: multivariate analysis of a long-term, prospective, population-based cohort. Ann Neurol 2001:49:336-344.
11. Lindsten $\mathrm{H}$, Nyström L, Forsgren L. Mortality risk in an adult cohort with a newly diagnosed unprovoked epileptic seizure: a population-based study. Epilepsia 2000;41:1469-1473.

12. Nashef $L$, Hindocha N, Makoff A. Risk factors in sudden death in epilepsy (SUDEP): the quest for mechanisms. Epilepsia 2007:48:859-871.

13. Colugnati DB, Arida RM, Cravo SL, et al. Hibernating mammals in sudden cardiac death in epilepsy: what do they tell us? Med Hypotheses 2008; 70:929-932

14. McLean BN, Wimalaratna S. Sudden death in epilepsy recorded in ambulatory EEG. J Neurol Neurosurg Psychiatry 2007;78:1395-1397.

15. Camfield P, Camfield C. Sudden unexpected death in people with epilepsy: a pediatric perspective. Semin Pediatr Neurol 2005;12:10-14.

16. Téllez-Zenteno JF, Ronquillo LH, Wiebe $\mathrm{S}$. Sudden unexpected death in epilepsy: evidence-based analysis of incidence and risk factors. Epilepsy Res 2005;65:101-115

17. Sillanpää M, Jalava M, Kaleva O, Shinnar S. Long-term prognosis of seizures with onset in childhood. N Engl J Med 1998;338:1715-1722.

18. Harvey AS, Nolan T, Carlin JB. Community-based study of mortality in children with epilepsy. Epilepsia 1993;34:597-603.

19. Lathers CM, Schraeder PL. Verbal autopsies and SUDEP. Epilepsy Behav 2009;14:573-576.

20. Camfield C, Camfield P. Twenty years after childhood-onset symptomatic generalized epilepsy the social outcome is usually dependency or death: a population-based study. Dev Med Child Neurol 2008;50:859-863.

21. Lin K, Benbadis SR. Death and epilepsy. Expert Rev Neurother 2009;9: 781-783.

22. Terra VC, Scorza FA, Cavalheiro EA, et al. Pediatric epilepsy surgery and sudden unexpected death epilepsy: the contribution of a Brazilian epilepsy surgery program. Childs Nerv Syst 2010;26:1075-1079.

23. Almeida AG, Nunes ML, Palmini AL, Costa JC. Incidence of SUDEP in a cohort of patients with refractory epilepsy: the role of surgery and lesion localization. Arq Neuropsiquiatr 2010;68:898-902.

24. Hitiris N, Suratman S, Kelly K, Stephen LJ, Sills GJ, Brodie MJ. Sudden unexpected death in epilepsy: a search for risk factors. Epilepsy Behav 2007; 10:138-141.

25. Scorza FA, Arida RM, Terra VC, Cavalheiro EA. What can be done to reduce the risk of SUDEP? Epilepsy Behav 2010;18:137-138. 